\title{
Formulasi Gel Nanopartikel Ekstrak Temulawak (Curcuma xantohrriza roxb.) Berbasis Kitosan Na-Tripolifosfat sebagai Antiacne
}

\author{
Deni Rahmat*, Deny Wirawan \\ Fakultas Farmasi Universitas Pancasila, Jakarta Selatan, 12640 \\ *Email korespondensi : mangnden78@yahoo.com
}

(Submit 15/03/2019, Revisi 05/09/2019, Diterima 20/12/2019)

\begin{abstract}
Abstrak
Temulawak mempunyai berbagai aktivitas biologi, diantaranya, antikanker, antiinflamsi dan antibakteri. Tujuan penelitian ini adalah memformulasi sediaan gel yang mengandung nanopartikel ekstrak rimpang temulawak sebagai antiacne. Gel yang terbentuk dievaluasi secara fisik meliputi: organoleptik, homogenitas, viskositas dan sifat alir, kemampuan menyebar; serta dilakukan evaluasi kimia yaitu pemeriksaan $\mathrm{pH}$ dan pemeriksaan mikrobiologi. Hasil menunjukkan baik gel ekstrak temulawak maupun gel nanopartikel ekstrak temulawak tidak mengalami perubahan warna dan tetap homogen. Viskositas gel ekstrak temulawak berkisar 153142,86 - 156333,33 cPs sedangkan gel nanopartikel ekstrak temulawak berkisar 133416,67 - 152702,38 cPs. Kemampuan menyebar gel ekstrak temulawak berkisar $56,53-58,46 \mathrm{~mm}$ sedangkan pada formula gel nanopartikel ekstrak temulawak berkisar 58,19-58,94 mm. Nilai pH gel ekstrak temulawak berkisar 7,1 sedangkan gel nanopartikel ekstrak berkisar 6,5. Daya hambat gel ekstrak temulawak berkisar 22,7 - $23 \mathrm{~mm}$, sedangkan gel nanopartikel ekstrak temulawak berkisar 26,3 - 26,95 mm. Aktivitas antibakteri gel terbesar adalah gel nanopartikel ekstrak temulawak. Dengan demikian, gel nanopartikel ekstrak temulawak dapat berpotensi sebagai sediaan gel antiacne.
\end{abstract}

Kata kunci: Temulawak, ekstrak, nanopartikel, antiacne

\section{Outline}

- Pendahuluan

- Metode

- Hasil dan Pembahasan

- Kesimpulan

- Ucapan Terima Kasih

- Daftar Pustaka

\section{Pendahuluan}

Temulawak (Curcuma xanthorrhiza Roxb.) merupakan tanaman obat yang telah dimanfaatkan secara empiris oleh leluhur bangsa Indonesia. Bagian rimpangnya digunakan secara tradisional untuk menangani berbagai gangguan kesehatan seperti sakit maag, diare, ambeien, batuk, asma, sariawan, dan berbagai penyakit lainnya ${ }^{1}$. Senyawa kurkuminoid merupakan salah satu komponen khas dan utama yang dapat ditemukan dalam ekstrak rimpang temulawak. Senyawa bioaktif ini diakui telah terbukti 
$a^{1-3}$. Sejumlah penelitian juga telah membuktikan bahwa komponen ini merupakan senyawa alami antimikroba berspektrum luas ${ }^{4}$.

Sejumlah pendekatan perlu dilakukan dalam rangka perbaikan karakteristik kurkuminoid agar dapat diperoleh hasil optimal dari penggunaannya. Metode-metode yang pernah diteliti di antaranya dengan pembentukan analog sintetis, kombinasi dengan bahan tambahan lain seperti adjuvan piperin, hingga strategi nanoteknologi yang dewasa ini gencar dimantapkan secara global 2,5 . Nanoteknologi terbukti menawarkan keuntungan yang besar, di antaranya meningkatkan uptake selular, laju disolusi, stabilitas dalam sirkulasi, fungsi pelepasan terkontrol dan tertarget, meningkatkan aktivitas farmakologis, dan lainnya ${ }^{6}$. Strategi nanoteknologi yang populer salah satunya adalah dengan pembentukan nanopartikel polimerik dengan menggunakan kitosan ${ }^{7}$.

Gel memiliki derajat kejernihan yang tinggi sehingga mempunyai nilai estetika yang baik dan kadar air tinggi yang dapat menghidrasi stratum corneum sehingga gel dipilh sebagai bentuk sediaan untuk memformulasi nanopartikel ekstrak temulawak yang dibuat menggunakan kitosan dengan metode gelasi ionik yang telah dikembangkan sebelumnya ${ }^{7}$. Gel yang akan dibuat menggunakan basis Carbopol ultrez 10 dengan konsentrasi $0,75 \%$.

\section{Metode}

\section{A. Bahan}

Ekstrak Etanol Temulawak (Balitro, Bogor), Carbopol Ultrez 10 (Probig Fine Chemical Co, Guangzhou, China) dan bahan tambahan Trietanolamin (Petronas), Propilenglikol, Dinatrium EDTA, Metil paraben (Ueno Fine Chemical), Propil paraben (Ueono Fine Chemical), Natrium metabisulfit (PT. Brataco), Air suling, Media Mueller Hinton Agar, Kaldu Pepton, Kitosan (Biotech Surindo), Na-Trpolifosfat (Hubei Xingfa Chemical).

\section{B. Metode}

1. Pembuatan Serbuk Nanopartikel Ekstrak Etanol Temulawak dengan Pengering Semprot

Pembentukan nanopartikel berdasarkan penelitian yang dilakukan oleh Yunahara dkk ${ }^{7}$. Suspensi nanopartikel ekstrak etanol temulawak dikeringkan dengan menggunakan pengeringan semprot (spray dryer). Optimasi suhu pengering semprot terhadap nanopartikel yang mengandung ekstrak etanol temulawak pada suhu inlet $185^{\circ} \mathrm{C}$, dan $195^{\circ} \mathrm{C}$. Kemudian dilakukan uji kadar air dengan syarat kadar air tidak lebih dari $10 \%$ untuk bahan alam.

\section{Formulasi Gel Ekstrak Etanol Temulawak}

i. Carbopol Ultrez 10 dikembangkan dalam air suling (beaker glass) sebanyak $60 \mathrm{~mL}$. Tambahkan sedikit demi sedikit trietanolamin sambil dihomogenkan dengan homogenizer sampai terbentuk basis gel (campuran $A$ ).

ii. Metil paraben dan Propil paraben dilarutkan kedalam sebagian propilenglikol, kemudian ditambahkan dinatrium EDTA yang telah dilarutkan sebelumnya kedalam air suling, dan natrium metabisulfit yang dilarutkan terlebih dahulu dengan air suling, kemudian masukan kedalam campuran A (campuran B).

iii. Tambahkan ekstrak etanol temulawak atau nanopartikel ekstrak temulawak kedalam campuran B sambil diaduk (campuran C). 
iv. Kemudian tambahkan parfum herbal yang telah dilarutkan ke sebagian propilenglikol. Setelah itu, semua bahan dihomogenkan dengan homogenizer dengan kecepatan dan waktu pengadukan yang optimal.

v. Gel yang dihasilkan dievaluasi yang meliputi organoleptik, homogenitas, viskositas dan sifat alir, kemampuan menyebar, dan $\mathrm{pH}$.

Tabel 1. Formula gel ekstrak temulawak

\begin{tabular}{|l|c|c|c|}
\multicolumn{1}{|c|}{ Bahan } & Blangko (\%) & Gel Ekstrak (\%) & $\begin{array}{c}\text { Gel } \\
\text { Nanopartikel (\%) }\end{array}$ \\
\hline Ekstrak temulawak & - & 0,5 & - \\
\hline Nanopartikel ekstrak & & - & $0,5 *$ \\
\hline Carbopol Ultrez 10 & 0,75 & 0,75 & 0,75 \\
\hline Propilenglikol & 15 & 15 & 15 \\
\hline Trietanolamin & 0,75 & 0,75 & 0,75 \\
\hline Natrium Metabisulfit & 0.1 & 0,1 & 0,1 \\
\hline Dinatrium EDTA & 0,05 & 0,05 & 0,05 \\
\hline Metil Paraben & 0,03 & 0,03 & 0,03 \\
\hline Propil Paraben & 0,01 & 0,01 & 0,01 \\
\hline Parfum Herbal & 0,01 & 0,01 & 0,01 \\
\hline Air suling sampai & 100 & 100 & 100 \\
\hline Keterangan : & $0,5 \%$ & & \\
\hline
\end{tabular}

Keterangan : ${ }^{*}=$ setara $0,5 \%$ ekstrak temulawak

3. Uji Aktivitas Antiacne Gel Ekstrak Etanol Temulawak dan Gel Nanopartikel Ekstrak Temulawak.

Media Mueller Hinton Agar (MHA) 25 mL ditambahkan suspensi bakteri 25\% T sebanyak $1 \mathrm{~mL}$, homogenkan dan diamkan selama 5 menit pada suhu kamar dan pada keadaan tertutup. Larutan uji ; $1 \mathrm{~g}$ gel ekstrak atau gel nanopartikel ekstrak temulawak dilarutkan dalam $3 \mathrm{~mL}$ aquadest steril (setara mengandung 0,5\% ekstrak etanol temulawak) kertas cakram steril direndam dalam larutan uji, kemudian kertas cakram steril diletakan pada permukaan media Mueller Hinton Agar. Diinkubasi pada suhu 370C pada inkubator selama 24 jam. Daerah bening disekitar kertas cakram menunjukkan adanya zona hambat bakteri8-10.

\section{Hasil dan Pembahasan}

\section{A. Hasil}

Berdasarkan hasil optimasi suhu pengeringan, didapat serbuk yang kering hasil pembuatan suspensi nanopartikel. Serbuk yang dihasilkan tidak lengket pada suhu $195 / 80^{\circ} \mathrm{C}$. Dan hasil uji kadar air pada serbuk tersebut memenuhi syarat dengan kadar air $<10 \%$. Hasil ini digunakan untuk penelitian selanjutnya. Nanopartikel dibuat dengan metode gelasi ionik yang telah dikembangkan sebelumnya dimana ekstrak temulawak dilarutkan dalam campuran pelarut etanol, propilenglikol dan DMSO kemudian dicampurkan dengan larutan kitosan $0,2 \%(b / v)$. Penambahan sodium tripolifosfat untuk menyambung silang kitosan sehingga bisa terbentuk nanopartikel ${ }^{7}$.

Gel ekstrak dan gel nanopartikel ekstrak temulawak berwarna jingga dan kuning muda, berbau parfum herbal. Gel blangko memiliki viskositas yang terbesar sesuai yang ditunjukkan pada Tabel 2. Hal ini disebabkan pada gel blangko tidak terdapat ekstrak ataupun nanopartikel ekstrak temulawak yang cenderung memiliki $\mathrm{pH}$ asam sehingga dapat mempengaruhi viskositas sediaan gel${ }^{7}$. Sedangakan gel nanopartikel ekstrak 
temulawak memiliki viskositas terendah. Kemampuan sebar sediaan gel terlihat pada Tabel 3 dimana gel blangko memiliki kemampuan menyebar yang paling kecil diantara gel ekstrak temulawak dan gel nanopartikel ekstrak temulawak. Namun demikian, gel blangko, ekstrak dan nanopartikel memiliki pH berturut-turut 7,2; 7,1 dan 6,5 yang masih aman untuk digunakan pada permukaan kulit. Berdasarkan Tabel 4, gel nanopartikel ekstrak mempunyai diameter daya hambat terbesar yang menunjukkan aktivitas antibakteri terbesar.

Tabel 2. Hasil evaluasi viskositas

\begin{tabular}{|l|l|}
\hline \multicolumn{1}{|c|}{ Formula } & \multicolumn{1}{c|}{ Viskositas (cps) } \\
\hline Blangko & 174166,67 \\
\hline Gel ekstrak temulawak & 153142,86 \\
\hline $\begin{array}{l}\text { Gel nanopartikel ekstrak } \\
\text { temulawak }\end{array}$ & 133416,67 \\
\hline
\end{tabular}

Tabel 3. Hasil evaluasi kemampuan menyebar

\begin{tabular}{|l|c|c|c|}
\hline \multirow{2}{*}{\multicolumn{1}{c|}{ Formula }} & \multicolumn{3}{c|}{ Kemampuan menyebar } \\
\cline { 2 - 4 } & $\mathrm{d}(\mathrm{mm})$ & $\mathrm{r}(\mathrm{mm})$ & $\mathrm{L}=\pi \mathrm{r}^{2}(\mathrm{~mm})$ \\
\hline Blangko & 49,26 & 24,63 & 1906,87 \\
\hline Gel ekstrak temulawak & 58,46 & 29,23 & 2685,08 \\
\hline $\begin{array}{l}\text { Gel nanopartikel ekstrak } \\
\text { temulawak }\end{array}$ & 58,94 & 29,45 & 2729,41 \\
\hline
\end{tabular}

Tabel 4. Aktivitas antibakteri gel

\begin{tabular}{|l|r|}
\multicolumn{1}{|c|}{ Sampel Gel } & $\begin{array}{c}\text { Diameter Daya } \\
\text { Hambat (mm) }\end{array}$ \\
\hline Gel blangko & $16,5 \pm 0,167$ \\
\hline Gel ekstrak temulawak & $22,89 \pm 0,13$ \\
\hline Gel nanopartikel ekstrak temulawak & $26,34 \pm 0,49$ \\
\hline Gel kontrol positif & $29,59 \pm 0,35$ \\
\hline
\end{tabular}

\section{B. Pembahasan}

Berdasarkan hasil pengamatan homogenitas, gel ekstrak dan nanopartikel ekstrak temulawak menunjukkan hasil yang homogen dengan ditandai tidak terjadinya pemisahan antara basis gel dan ekstrak maupun nanopartikel ekstrak temulawak serta bahan-bahan komponen penyusun gel lainnya. Hal ini disebabkan pada proses sebelumnya telah dilakukan uji optimasi terhadap pencampuran gel yakni kecepatan pengadukan dan waktu pencampuran yang optimum. Sehingga diperoleh hasil gel yang homogen. Semua sediaan gel memiliki sifat ailir yang sama yaitu plastis. Hal ini dikarenakan kurva meningkat dan menurun berhimpit dan memiliki yield value. Terdapatnya ekstrak temulawak ataupun nanopartikel ekstrak temulawak mempengaruhi viskositas menjadi lebih rendah, viskositas yang lebih rendah menyebabkan kemampuan sebar menjadi meningkat dan tekanan yang dibutuhkan suatu sediaan menjadi semakin kecil. Diameter penyebaran gel blangko, gel ekstrak dan gel nanopartikel ekstrak temulawak dikategorikan sebagai gel setengah padat. Hasil menyebar ini menunjukkan sediaan gel yang cukup untuk menyebar saat diaplikasikan dan mampu mengelir dari tube dengan baik. 
Sediaan topikal yang terlalu asam atau basa dapat merusak mantel kulit, sehingga menyebabkan berkurangnya perlindungnan kulit dari serangan mikroorganisme. Pada gel blangko memiliki pH terbesar. Hal ini dikarenakan gel tersebut tidak mengandung ekstrak ataupun nanopartikel ekstrak temulawak. Sedangkan $\mathrm{pH}$ terendah dihasilkan dari gel nanopartikel ekstrak temulawak. Hal ini karena pada proses pembuatan nanopartikel ekstrak temulawak untuk melarutkan kitosan digunakan asam asetat glasial ${ }^{7,11}$. Selain itu, gel nanopartikel ekstrak mempunyai aktivitas antibakteri terbesar karena nanopartikel mempunyai penetrasi yang baik dalam medium agar dan membran sel bakteri.

\section{Kesimpulan}

Nanopartikel ekstrak temulawak dengan matriks kitosan dapat diformulasi menjadi sediaan gel dengan basis carbopol dan menunjukkan aktivitas antibakteri yang lebih besar daripada gel ekstrak temulawak.

\section{Ucapan Terima Kasih}

Ucapan terima kasih ditujukan kepada Ristek DIKTI atas dana yang diberikan dalam skema PDUPT

\section{Daftar Pustaka}

1. Afifah E. Sehat dengan ramuan tradisional: Khasiat dan manfaat temulawak rimpang penyembuh aneka penyakit. Jakarta : Agromedia Pustaka; 2003. p.8-9, 22, 34-38.

2. Anand P, Kunnumakkara AB, Newman RA, Aggarwal BB. Bioavailability of curcumin: problems and promises. Mole Pharma, 2007;4:807-818.

3. Lao CD. Dose Escalation of a Curcuminoid Formulation. BMC Complement Altern Med, 2006;6:10.

4. Hamed OA, Mehdawi N, Taha AA, Hamed EM, AI-Nuri MA, Hussein AS. Synthesis and antibacterial activity of novel curcumin derivatives containing heterocyclic moiety. Iran J Pharm Res, 2013;12:47-56

5. Bisht S, Feldman G, Soni S, Ravi R, Karikar C, Amarnath M, et al. Polymeric Nanoparticle-encapsulated Curcumin ("Nanocurcumin") A Novel Strategy for Human Cancer Therapy. Journal of Nanobiotechnology, 2007:5(3):1-18

6. Mahajan Y. Nanotechnology-enhanced curcumin: Symbiosis of ancient wisdom with modern medical science [Online]. Diakses pada tanggal 10 Februari 2017. Diambil dari: http://www.nanowerk.com/spotlight/spotid=22677.php

7. Farida, Y., Rahmat, D. Uji Aktivitas Antiinflamasi Nanopartikel Ekstrak Etanol Rimpang Temulawak (Curcuma xanthorrhiza Roxb.) dengan Metode Penghambatan Denaturasi Protein. Jurnal IImu Kefarmasian Indonesia, 2018;16(2):225-230.

8. Balouiri, M., Sadiki, M., Ibnsouda, S.K. Methods for in vitro evaluating antimicrobial activity: a review. J. Pharm. Anal., 2016;6:71-79.

9. Arullappan, S., Zakaria Z., Basri, D.F. Preliminary screening of antibacterial activity using crude extracts of Hibiscus rosa sinensis. Trop. Life. Sci. Res., 2009;20:109118. 
10. Bhalodia, N.R., Shukla, V.J. Antibacterial and antifungal activities from leaf extracts of Cassia fistula I.: an ethnomedicinal plant. J. Adv. Pharm. Technol. Res. 2011; 2:104-109

11. Mardliyati, E., El Muttaqien, S., Setyawati, D.R. Sintesis nanopartikel kitosantrypoly phosphate dengan metode gelasi ionik: pengaruh konsentrasi dan rasio volume terhadap karakteristik partikel. Prosiding Pertemuan IImiah IImu Pengetahuan dan Teknologi Bahan, Serpong; 2012. p. 90-93 